\title{
RESENSIE :
}

(i) VOORI,CPFRS VAN IDIE HFRVURMINH;

(ii) MAARTTEN I,UTHHER

(iii) JOHANNES CALVYN

Rnoks F2: Brosjurns van die IRS, Putehefstroom, 1985 ness, 29, 31, 30, dnilr Dr. G.(:. de Groot)

llierdie mooi reeks "Reformatoregalery" sluit aan by besondere datuns en is gobore uit die ontstellende feit "dat ons huidige geslag Afrikaners - selfs die wat hulle as die gepstelike nasate van die sestiende-eruse Hervorming beskou - mar min van "die geloofshelde van die Hervorining weet" ("Vooraf"), p. (i). In "kor-t hrosjures in eenvoudige taal" word "iets oor die figure se Iner vermeld". maar die hoofklem val "op liulle lewe".

In die eerste bogenoemde brosjure word Arnold van Brescia, Jnhn Wveliff en Johannes llus behandel. Die spelling verdien aanday: By John Wycliffe ontbreek 'n "e" en llus word met een "s" gespel, soos op die agterblad warop in lys van dif nommers van die reeks verskyn. Hulle word tereg in verband gebring met die tema "opstand teen die pouslike mag" (p. 1-2). Of hulle in "irbellie" aangevoer het (p.2), is "vraag. Hulle wou die kerk bevry van die pouslike mag en het na in regstelling van die misstande gesoek.

Arnold is ' $n$ goeie keuse (p. 3-G). Ons weet so min van hom - en kerkhistorici onderskat sy invloed. Miskien kon daar iets meer oor die inhoud van sy standpunt gesê grwees hel

Die "persoon wat die vlam van verset verder sou versprei". was inderdaad John Wycliffe (p. 1.15), die "groot patriot" (p.71). Sy .?69- 
standpunt word kerkhistories gestel en uitgeklaar. "Na 'n grondige studie van die Ileilige Skrif kom Wycliffe hoe langer hoe meer tot die oortuiging dat die Rooms-Katolieke Kerk reeds oneindig ver van die eerste beginsels van Jesus se leer algewyk het. Ook gaan sy oë oop vir die misstande wat daar in die kerk heers" (p.8). "n Historiese Iyn word dan deurgetrek na Hus, die "geloofsheld en martelaar" (p.16). Ook die lewenskets van hierdie Bohemer (p.16-27), is insiggewend en prikkelend gestel. Dit word met die Hervorming in verband gebring. Dat "die Boheme die eerste Protestantse nasie in Europa" (p. 26) is, is miskien te veel gesé, as "Protestants" met 'n hoofletter gespel word. Die Iyn word selfs na Suid-Afrika deurgetrek, en daar word vermeld dat die Hussicte deel geword het van die Morawiërs en George Schmidt (nie Robert nie, p.26) wat in 1737 sendingwerk aan die Kaap kom doen liet.

As l.uther aan die beurt kom. word daar heelwat agtergrond vir sy "jeug en bekering" uitgespel (p. 1-8). lets word gesê oor hoe Luther se lewe geïnterpreteer moet word. In Historiese benadering word egter behou en by die gangbare interpretasie aangesluit. H. Bavinck word aangehaal on daarop te wys dat "In de hervormingstijd beleed men zijn geloof, later geloofde men zijn belijdenis" (p.2()). Reeds by l.uther moet 'n mens tussen "Die jong Luther en die ou Luther" onderskei (p.35 e.v.). Van heldeverering is hier geen sprake nie. Die Hervormer se lewe word vertel en daarmee ook van die hervorming van die kerk. Ten slotte word gewys op "die belangrikheid van I.uther se teologie vir vandag in Suid-Afrika" (p. $52-55)$.

Die brosjure oor Johannes Calvyn (1509-1564) loop ook vanuit 'n historiese oorsig van sy lewe op 'n leerstellige samevatting uit. Op p. (i) moet twee foutjies reggestel word. Calvyn is op 10 Julie 1509 gebore, nie 1504 (p.(i)) nie. Hy was 55 jaar oud by $s y$ afsterwe, nie "vyf-en-veertig" nie (p.1). Hier is "n Calvinis aan die woord oor Calvyn. Hy laat hom in sy beskrywing en beskouings leef. Dit is 'n uiters geslaagde skets vir die gereformeerde lidmat en ook vir hulle wat vreemd teenoor Calvyn staan. Calvyn se "leer en persoonlikheid" (p. 47-60) word tereg saam gestel. In aansluiting by Luther voer hy selfstandig die uitleg van die Woord en die hervorming van die kerk verder. 
Om van die kerklike organisasie waraan Calvyn gevolg gegee liet, as "proslitiexinans" te praat, is seker nie heeltemal reg nie (p.52). Dit moet "presbiteriaal" wees; in die Engelse wîreld hot dit uitgeloop op "presbiteriaans". Mont "n mens nie maar liewer van "n "kerkorde" as "kerkorganisasie" praat nie? 'n Mens muet seker ouk lirwer perder van "uitverkiesing" as van "voorbeskikking" of "predestinasie" praat (p. 53).

lifer en daar kon in die drie borsjures interessante wonde voor, bv. n "vinsige" kelder, (v, p.21), "vermufde"; "gekrys" (v., p.23), "geskree"; "grif", (c., p.58), "grredelik".

Die predikante kan gerus hierdie brosjures koop. Daar is meer llervormers wat in die reeks behandel word, soos wat die agterblad aandui. Dan sal hulle hierdie brosjures vir hulle kategese wil gebruik en by lidmate aanbeveel.

E. Brown

Fakulteit Teologie, Stellenbosch 